\title{
Performance of the PV Subsystems in Smart Micro Grid Sumba
}

\author{
Kholid Akhmad $^{1}$, Eka Nurdiana ${ }^{2}$, Nur Aryanto Aryono ${ }^{3}$, Hamzah Hilal ${ }^{4}$
}

\begin{abstract}
Smart Micro Grid (SMG) Sumba is inaugurated in

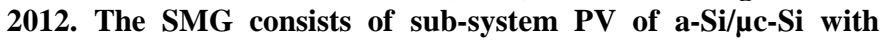
capasity $500 \mathrm{kWp}$, smart generator of $2 \times 135 \mathrm{kVA}$, VRB of 2x240 $\mathrm{kWh}$, and sub-system control and data communication. The output of the SMG is connected to the grid at $20 \mathrm{kV}$. Sub-system PV is connected to the 5 unit's inverter of PV-grid type with each power capacity of $100 \mathrm{~kW}$.
\end{abstract}

At the beginning of operation, sub-system PV is operated at maximum level (100\%). Electrical power is about $400 \mathrm{~kW}-500$ kW supplied to the grid in clear daytime continuously from 10:00-15:00. When it is cloudy, the electrical energy supplied to the grid varies according to fluctuations in the intensity of light on the surface of PV arrays. Base load during the daytime in Southwest Sumba Regency at the time is about $1.5 \mathrm{MW}$, meaning that the contribution of electric energy of PV array is almost $30 \%$. The change of cloud abruptly causes the output of PV to drop significantly, which could lead to black out at the local grid because the generators of PLN are not able to cover the power loss immediately. These restrictions result in Sumba SMG can not be operated optimally. Local power company can not tolerate frequent black outs due to the fluctuating of power injection from PV array.

Over time some of the components of VRB are damaged so that the VRB is not enabled. Then, the SMG is applied to the extent of PV-grid connections, with the restriction of the power output of PV array at a rate of $30 \%$, or power supplies $150 \mathrm{~kW}$ continuously during the daytime. As the SMG has been operated for about four years, the performance of the PV array has degraded about $20 \%-30 \%$. The changes evidenced in the form of an electric current-voltage curves of PV module are measured by Sun-Simulator.

In this paper, it is also discussed general information about the SMG system built in Southwest Sumba Regency, and specifically reviewing the performance of the sub-systems PV since it was built until now.

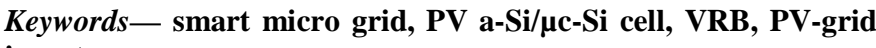
inverter

\section{INTRODUCTION}

Demo plant Sumba SMG is intended as a place to assess the penetration of renewable forms of energy generation (Energi Baru Terbarukan/EBT) into another grid that has a fairly large scale penetration. The concept of micro grid itself is an approach with the power plant and load that can be seen as a subsystem. From this approach, the system will consist of clusters so that this is more likely to control locally in an

${ }^{1}$ Researcher,Badan Pengkajian dan Penerapan Teknologi, Jl. MH. Thamrin No. 8, Jakarta, INDONESIA(tlp: 021-75791366; fax: 021-75791366; e-mail: kholida@ymail.com)

2,3,4 Engineer, Badan Pengkajian dan Penerapan Teknologi, Jl. MH. Thamrin No. 8, Jakarta, INDONESIA(tlp: 021-75791366; fax: 021-75791366; e-mail:eka.nurdiana@bppt.go.id; nuraryantoaryono@yahoo.com,taura889@yahoo.com) electrical network [1]. EBT plant that is used in this study is a plant of the cell (module) photovoltaic (PV) with capacity of $500 \mathrm{kWp}$.

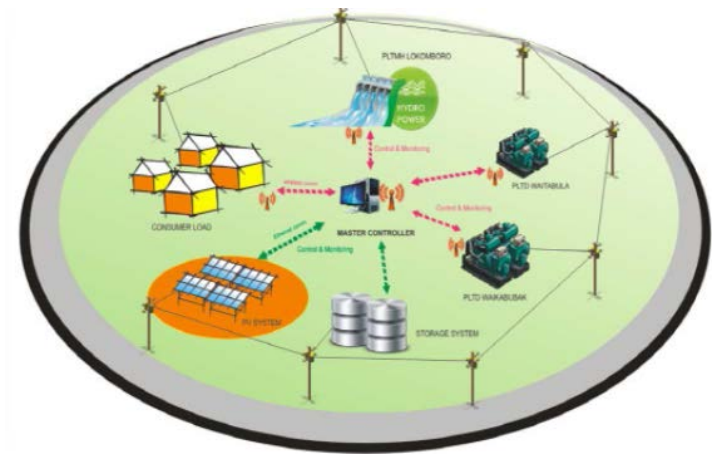

Fig. 1 Schematic System of "smart micro grid” in Southwest Sumba Regency.

Due to the PV power plant characteristics that are intermittent, highly dependent on the intensity of light on the surface of the PV module, therefore when it is integrated into the grids, it should be backed up by the resource plant or energy storage plant that can substitute the decreased power result in PV module immediately [2]. At the Sumba SMG system, as a backup of the PV subsystem, it uses the energy storage subsystem that is flow battery called Vanadium Redox Battery (VRB) with capacity of $480 \mathrm{kWh}$ equipped by Power Conversion System (PCS) with capacity 2x240 kW. Besides the battery subsystem, the SMG Sumba is also equipped by the backup of diesel power plant (Pembangkit Listrik Tenaga Diesel/PLTD) namely smart generator which has the features for remote control with the generator capacity $2 \times 135 \mathrm{kVA}$. The hybrid system is able to realize the energy self-sufficient village (Desa Mandiri Energi/DME), which can suffice 60\% of the total energy needs (electricity and fuel) by empowering potential of local resources and increasing the productive activities to improve the economy of the village as the impact of the availability of local energy [3].

In order to integrate the three subsystems, namely: PV, battery, and smart generator into the grid, the subsystems need adequate control and monitor systems. Therefore, this SMG system uses technology Information \& Control Technology (ICT). In addition, this subsystem known as Supervisory Control and Acquisition Data (SCADA) functions to monitor all of the SMG Sumba subsystems and PLN West Sumba electrical system (PLTD Waitabula, PLTD Waikabubak, and PLTMH Lokomboro).

Fig. 1 shows a schematic system of "smart micro grid" built on the electrical system in Southwest Sumba Regency. This system consists of power plant of renewable energy resource, namely PV and MHP located in Bilacenge and Lokomboro, conventional power plants (PLTD) in Waitabula and 
Waikabubak region, electrical power storage subsystem (battery bank, VRB), controller subsystem, and user. All of subsystems are controlled via a satellite (VSAT) located in Bilacenge region, the location of the PV subsystems construction.

TABLE I

The POWER Plant In West Sumba

\begin{tabular}{|l|l|l|l|}
\hline \multicolumn{1}{|c|}{$\begin{array}{c}\text { Plant/ } \\
\text { Location }\end{array}$} & Total of Plant & $\begin{array}{c}\text { The } \\
\text { Power of } \\
\text { Capacity } \\
\mathbf{( k W )}\end{array}$ & \multicolumn{1}{|c|}{ Information } \\
\hline $\begin{array}{l}\text { PLTD } \\
\text { Waikabubak }\end{array}$ & 9 generators & 2300 & 8 PLN, 1 lease \\
\hline $\begin{array}{l}\text { PLTD } \\
\text { Waitabula }\end{array}$ & 6 generators & 2170 & $\begin{array}{l}\text { 2 PLN, 2 } \\
\text { leases, 2 BPPT }\end{array}$ \\
\hline $\begin{array}{l}\text { PLTMH } \\
\text { Lokomboro }\end{array}$ & 5 generators & 2200 & 5 PLN \\
\hline $\begin{array}{l}\text { PV } \\
\text { Subsystems }\end{array}$ & 1 unit & $500 \mathrm{kWp}$ & Bounded 30\% \\
\hline VRB Battery & 1 unit & $2 \times 240$ & DOD 80\% \\
\hline
\end{tabular}

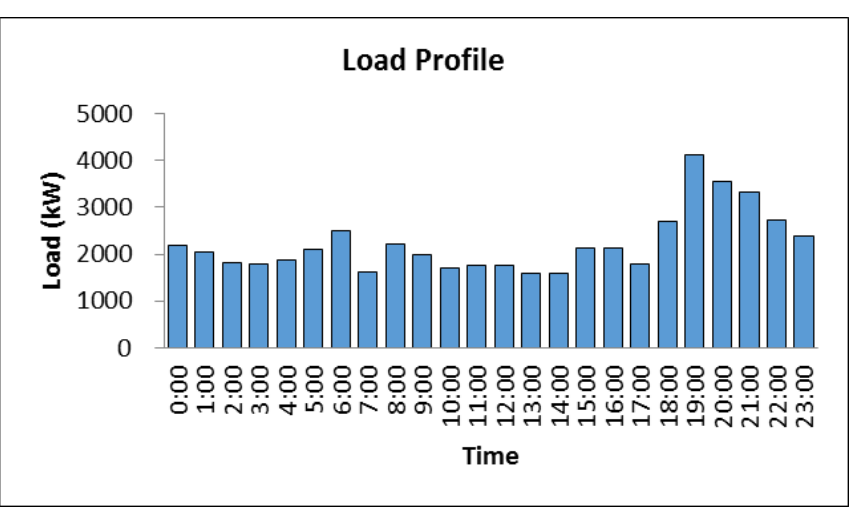

Fig. 2 The Curve of Daily Load West Sumba System in 2014

PLTMH located in Lokomboro is connected with PLTD Waikabubak. Nowadays, among Waitabula and Waikabubak has been connected with the system at $20 \mathrm{kV}$, so that the electrical system in West Sumba has been supported by the third power plant systems, namely PLTMH, PLTB, and PV power plant. The construction of transmission lines of about $20 \mathrm{kV}$ to connect West Sumba with East Sumba is ongoing. From Table I, it can be seen the power plant in West Sumba.

At the beginning of the development of SMG program in Sumba, in 2010, it was conducted a study on the load in PLTD Waitabula. At that moment, PLTD Waitabula and PLTD Waikabubak have not been interconnected yet. The amount of base load is about $800 \mathrm{~kW}$, meanwhile the peak load is about $1500 \mathrm{~kW}$. In $16^{\text {th }}$ June 2013, it was recorded that base load increased to be $1250 \mathrm{~kW}$, meanwhile the peak load increased to be $2100 \mathrm{~kW}$. In 2014 the load of Sumba system kept increasing as it was recorded that the daily peak load was about 4,1 MW as shown in Fig. 2.

By the interconnection between Waitabula system and Waikabubak system, the electrical network system becomes very different from the beginning of development plant in Sumba. The number of plant increases and the load also increases, additionally the subsystem of VRB battery has not worked so that the penetration of the PV subsystem is bounded $30 \%$ from the total of capacity. Therefore, the percentage of the PV penetration to the grid is rather small.

\section{PV SUBSYSTEMS}

\section{A. PV Array}

Every PV array consists of six units of PV module that are connected in series. The type of PV cell used is amorphous silicon (a-Si) using the technology of the double junctions (a$\mathrm{Si} / \mu \mathrm{c}-\mathrm{Si}$ ) with the conversion efficiency of about $10 \%$. The specification of each PV module can be seen in Table II.

TABLE II

The Specification of PV Module Thin Film at SMart Micro Grid

\begin{tabular}{|c|l|c|}
\hline No. & \multicolumn{1}{|c|}{ Parameter } & Specification \\
\hline 1. & The nominal power & $110 \mathrm{~W}$ \\
\hline 2. & The voltage of open circuit $\left(\mathrm{V}_{\mathrm{oc}}\right)$ & $126.5 \mathrm{~V}$ \\
\hline 3. & The influx of short circuit $\left(\mathrm{I}_{\mathrm{sc}}\right)$ & $1.45 \mathrm{~A}$ \\
\hline 4. & Maximum voltage $\left(\mathrm{V}_{\mathrm{mp}}\right)$ & $93.6 \mathrm{~V}$ \\
\hline 5. & Maximum influx $\left(\mathrm{I}_{\mathrm{mp}}\right)$ & $1.17 \mathrm{~A}$ \\
\hline 6. & The maximum voltage system & $1000 \mathrm{~V}$ \\
\hline 7. & Dimension (pxlxt) cm & $130 \times 110 \times 0.68$ \\
\hline 8. & Load per- PV module & $23 \mathrm{~kg}$ \\
\hline
\end{tabular}

Every 38 to 40 units of PV array are connected in parallel with DC bus in combiner box which produces Voc about 759 volt, current $\mathrm{I}_{\mathrm{sc}}$ of about 55 ampere, and the maximum of power output of about $25 \mathrm{~kW}$. The combiner boxes installed are about 20 units, so that total of maximum power PV subsystem is about $500 \mathrm{~kW}$. In each of two units of the combiner box are parallel in one unit of collection box, so that there are 10 units of collection box installed precisely next to the combiner box. In addition, in each of two units of collection box with the power output $100 \mathrm{kWp}$ is connected in parallel in input inverter of grid tied type with capacity 100 $\mathrm{kW}$ and the operating voltage in range 450 VDC - 850 VDC. Therefore, there are five inverter units installed in control room. The inverter is equipped with synchronize feature into grids in the voltage system 400 VAC which has anti islanding feature. If there is instability in grids, the inverter automatically OFF or separates from the grids to ensure the safety of grids and the operator will fix issues that are occurring. The electrical output of the fifth inverter is supplied to secondary network at $20 \mathrm{kV}$ via set up transformer at 630 $\mathrm{kVA}$ [4].

Fig. 3 and Fig. 4 show PV array $a-S i / \mu c-S i$ and the fifth inverter units of grid tied type. The formatting of series or parallel networking from PV module follows the inverter specifications, furthermore, it is adapted to the electrical specifications of the PV module. The installation of PV subsystem at $500 \mathrm{kWp}$ which has thin film type is the first installation of the PV subsystem in Indonesia, and it becomes a job for BPPT to do assessment of their performance for the condition or weather in Indonesia. 


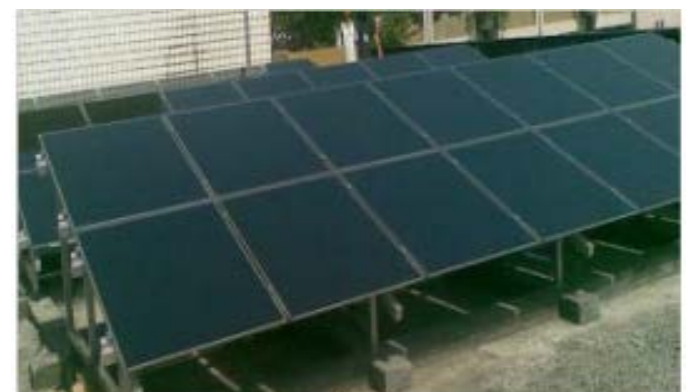

Fig. 3 PV Array with $a$-Si/ $\mu c-S i$ type the power capacity $100 \mathrm{Wp}$ per-module.

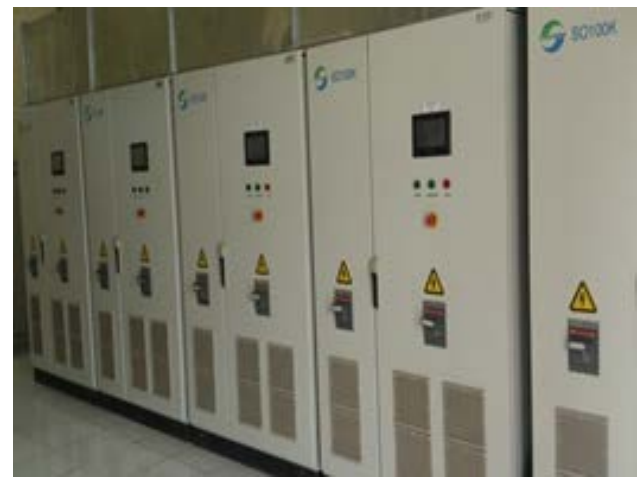

Fig. 4 Five inverter units of PV-grid Type (@ 100 kW).

\section{B. The Performance of PV Subsystem}

1) At The Beginning of Operating System: At the beginning of the opening SMG Sumba, in 2012, PV subsystem was operated according to maximum power point tracker (MPPT) procedure or no power limit procedure $(100 \%)$. In each inverter LCD, it is shown that the power output has almost the same result to the PV power input that is about $106 \mathrm{~kW}$ which produces the AC power output is about $99.7 \mathrm{~kW}$, then it is distributed into grids. Recorded on 11 May 2012, at 10:21 PV subsystem could produce the power output almost $500 \mathrm{~kW}$ from all of the fifth inverter units, such as it can be seen in Fig. 5. The other parameters, such as current and voltage of the side of grids, frequency, and inverter operation duration on that day are shown in the same display.

The power supply of PV subsystem which is relatively steady at $500 \mathrm{~kW}$ from the output of the fifth inverter units in clear daytime starts from 10 o'clock until afternoon at 14:30 is very helpful to supply the electrical energy in Southwest Sumba regency which has base load in daytime of about 1,500 $\mathrm{kW}$ as seen in Fig. 2. However, the problem appears when the weather changes quickly, such as there is cloud that it is blocked out the sunlight to the PV module surface. That condition will decrease the PV power output significantly and immediately. If the electrical energy decreases up to 200-300 $\mathrm{kW}$, the PLN diesel cannot cover the weakness of electrical power in short time. The weakness of electrical power that appears immediately should be overcome by VRB battery. However, the function of VRB itself has problem since the beginning of the development so that it cannot be able to function as the initial design. This case can affect the supply demand condition does not balance so that it can cause outage in overall network. This situation is not expected to occur repeatedly by PLN in every region, therefore to anticipate this case, it is approved that the PV power output is limited 30\% from the maximum capacity or it is about $150 \mathrm{~kW}$. This limitation point will be maintained by PV subsystem although there is transformation of light intensity which is quite significant which means that the PV subsystem will be able to give the electrical power output of about $150 \mathrm{~kW}$.

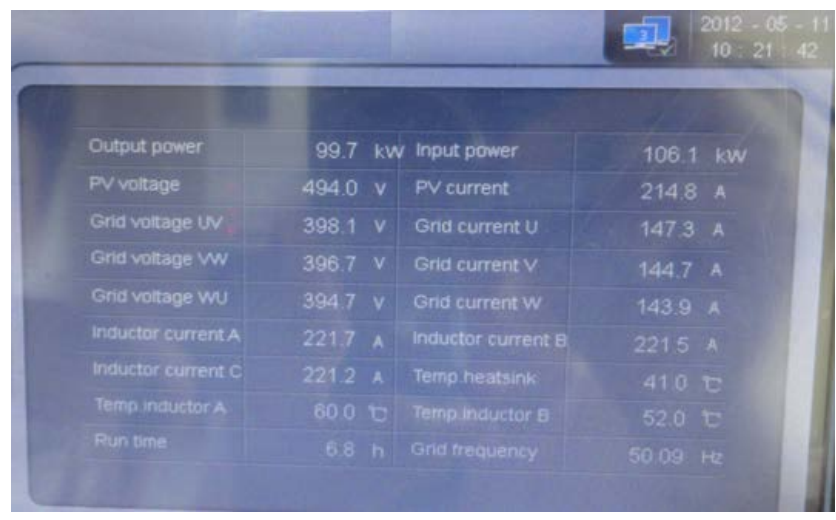

Fig. 5 The parameter output in one of inverter LCD.

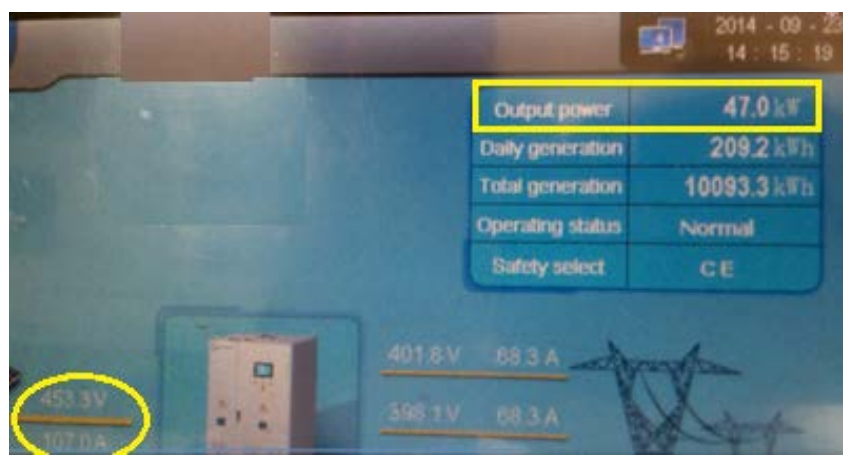

Fig. 6 The reduction of performance of PV array.

2) The Decrease Performance of PV Array: The decrease performance of PV array was discovered after the PV array had been operated almost 2.5 years. That condition was shown with the decrease point of the operating voltage PV array as seen in Fig. 6. The inverters are operated fully, means the limitation the power output $30 \%$ can be returned to $100 \%$. In clear weather condition with the light intensity as it is almost equal to the result shown in Fig. 5, the power output in Fig. 6 only produces about $47 \mathrm{~kW}$ at the inverter operating voltage of about 453 VDC. Meanwhile, from the Fig. 5, it can be seen that the power output about $106 \mathrm{~kW}$ from the inverter operating voltage is about 494 VDC. In this case, it has occurred the degradation of the power of the PV system that is quite sharp that causes the value of power output itself drops significantly too. The power value shown by the inverter above is 453 VDC. The critical lower limit of inverter is 450 VDC. It means that if the current of the operational array PV is below 450 VDC, the inverter will separate from grids automatically [5].

It is predicted one of the main factors that caused the reduction of power output PV array occurred drastically was that the pole of PV negative array had not been installed to the grounding for a long time, which were 6 months. The result of 
literature study shows that there is damage on TCO layer in the PV cell surface because of the PV pole negative array which has thin filma-Si type was not grounded. It could cause excessive electrical charges on the surface of the PV cell, so that the TCO layer on the surface of the PV cell would damage. TCO layer on the surface of the PV cell has a function as an anti-reflection layer as well as a transparent conductor layer that carries the electrons is produced PV cells to the negative electrode of the cell.

The reduction of the performance PV array significantly influences the quality of electrical power in the side of grid, because the inverter often separates or off line from the grid when the inverter is operated to the maximum level (no limitation of power output). To overcome this condition, the power output of the PV array should be limited again about $30 \%$, so that the value of the operational voltage is above the minimum limit of the inverter operating voltage (> 450 VDC).

3) Re-wiring PV Array: In attempt to improve the performance of PV arrays, this has been done re-wiring between the PV modules. At first a single unit of PV array consists of six units of PV modules connected in series. By the re-wiring, every new PV array is composed of seven units of $\mathrm{PV}$ modules connected in series, which means that one unit of PV modules added to each unit of the old PV arrays. Rewiring is only done specifically for the PV array that connected to the inverter number 5 with the power capacity about100 kWp. With the existence of re-wiring, the PV module remains five units unused. The result of the power output of the inverter number 5 after re-wiring the PV array compared to the power output of inverter number three measured at the same time are shown in Table III. It is apparent from the table, when the both of the power output of inverter is set at $35 \%$, the operating voltage VDC of inverter number 5 is higher than the inverter number 3 with the PV array that has not been re-wiring. This means, the operating voltage of inverter number 5 is safer than the inverter number 3 if it is associated with a lower limit value of the operating voltage of inverter (450 VDC). It is also apparent as the power output of the types of inverter is almost same even though there is a difference of five units of PV module on the inverter number 5 that is not installed. From these results, at least there are two advantages of the results of re-wiring the PV array, the inverter of electrical power output number 5 higher than the inverter number 3 in the same range of operating time, which every inverter shows about $9.0 \mathrm{kWh}$ and $6.8 \mathrm{kWh}$, and for the same operating of the inverter operating voltage about 455 VDC, then the inverter number 3 shows the power output about $36 \mathrm{~kW}$, while the inverter number 5 was about $48 \mathrm{~kW}$.

The differences of electrical energy are produced from the both of the inverters can be explained as follows. When the setting the power output is at $35 \%$, it does not mean that the operating voltage of the both inverters is constant at $495.8 \mathrm{~V}$ and $602.8 \mathrm{~V}$. The cloud that appears suddenly will decrease the voltage of PV array quietly intense. The example is the reduction of the voltage about $60 \mathrm{~V}$ because of the influence of the cloud, it produces the operating voltage of inverter number 3 at $435.8 \mathrm{~V}$, and this point already causes the inverter number 3 to seperate from grids (off line). Meanwhile, the decline of the operating voltage inverter number 5 is at 542.8
$\mathrm{V}$. This point is still above the minimum inverter value at 450 $\mathrm{V}$, so that the inverter number 5 still works. Meanwhile, the inverter number 3 is still in the position of waiting for the cloud to disappear so that the PV array voltage increases again, and the inverter number 3 takes a time to synchronize again on the grids (on line).

TABLE III

THE COMPARISON OF THE PARAMETER OUTPUT ELECTRICITY IN LCD INVERTER NUMBER 3 AND NUMBER 5

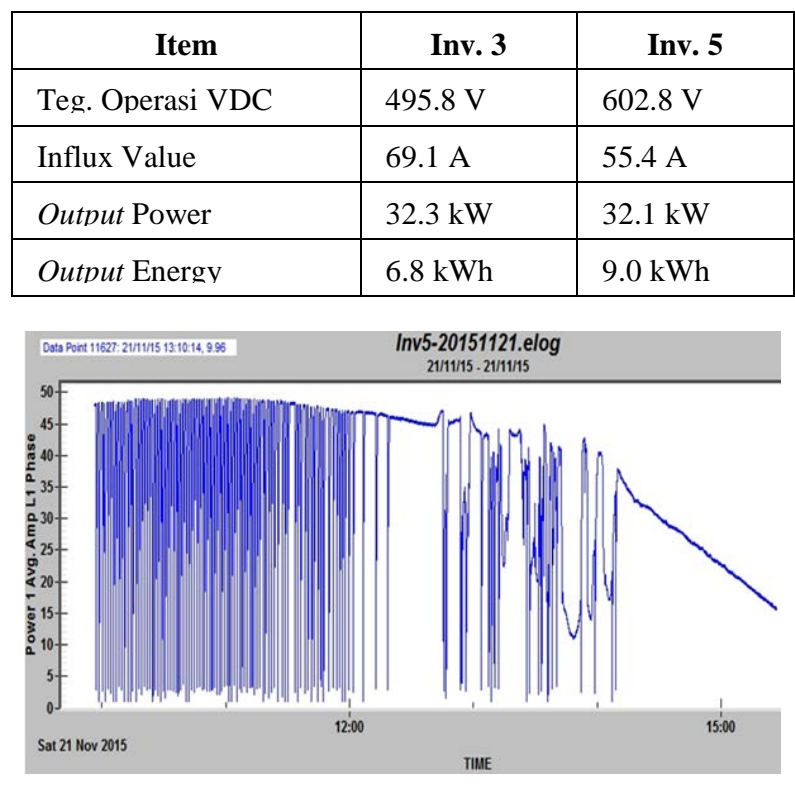

Fig. 7 The curve of power output of inverter number 5 that shows the frequency of the inverter off from the grids.

From the observation, it appears that the re-wiring has not been able to overcome the problems of the frequency when the inverter is off from the grids because the minimum operating voltage inverter, which is $450 \mathrm{VDC}$, still often passes although the frequency that is not as often as the inverter with the PV array that has not been re-wiring. From Fig. 7, it can be seen that the curve of power output of inverter number 5 connected with PV array which has been re-wiring. It is seen clearly that the inverter often separates from the grids even though the power output of the inverter number 5 is limited at 50\%.

4) The Examination of the I-V curve of PV modules: To know that there has been degradation in the electrical output of PV modules, we do measurement of the characteristics of current-voltage module $\mathrm{PVa}-\mathrm{Si} / \mu \mathrm{c}-\mathrm{Si}$ in the B2TKE laboratory using Sun Simulator in standard conditions (Standard Test Conditions, STC). The results of the next measurement compared with the measurement on the same conditions at the beginning of the PV modules were fabricated, by AURIA manufacturer in Taiwan. The results of I-V characteristics in B2TKE-BPPT can be seen in Fig. 8, while in Table IV shows the comparison of the electrical parameters of the PV module output at the beginning of the assembled in 2011, and after it was used in the early 2016, and the specifications matched the label on the back of the PV modules. 


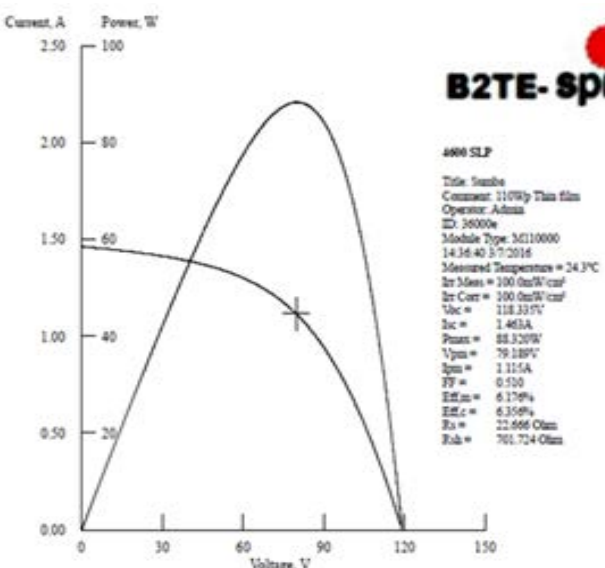

Fig. 8 The characteristics of influx-voltage (I-V) PV module a-Si/ $\mu \mathrm{c}-\mathrm{Si}$ on March 7, 2016.

TABLE IV

The Comparison Of MEASUREMENT RESUlts AND SPECIFICATION PV A$S I / \mu C-S I$ MODULE

\begin{tabular}{|l|c|c|c|c|c|c|}
\hline $\begin{array}{c}\text { Measurement } \\
\text { Result/ } \\
\text { Specification }\end{array}$ & $\begin{array}{c}\mathbf{I}_{\text {sc }} \\
\mathbf{( A )}\end{array}$ & $\begin{array}{c}\mathbf{V}_{\text {oc }} \\
\mathbf{( V )}\end{array}$ & $\begin{array}{c}\mathbf{I}_{\mathbf{m p}} \\
\mathbf{( A )}\end{array}$ & $\begin{array}{c}\mathbf{V}_{\mathbf{m p}} \\
\mathbf{( V )}\end{array}$ & $\begin{array}{c}\mathbf{P}_{\mathbf{m}} \\
\mathbf{( W )}\end{array}$ & $\mathbf{F F}$ \\
\hline $\begin{array}{l}\text { 16 Agust' 2011 } \\
\text { (Auria-Taiwan) }\end{array}$ & 1.57 & 125.4 & 1.37 & 91.4 & 125 & 0.63 \\
\hline On the label & 1.45 & 126.5 & 1.17 & 93.6 & 110 & 0.59 \\
\hline $\begin{array}{l}\text { 7 Maret 2016 } \\
\text { (B2TKE-BPPT) }\end{array}$ & 1.46 & 118.3 & 1.10 & 79.2 & 88.3 & 0.50 \\
\hline
\end{tabular}

From Table IV, it can be seen the difference in the number of direct measurements in AURIA-Taiwan, especially the maximum power output $\left(\mathrm{P}_{\mathrm{m}}=125 \mathrm{~W}\right)$ with the numbers on the label $\left(\mathrm{P}_{\mathrm{m}}=110 \mathrm{~W}\right)$. It should be noted that the PV modules $a-S i / \mu c-S i$ when the process of assembling has undergone the annealing treatment in the chamber. It means that the electrical characteristics of the PV modules have remained in steady condition. If we refer to the results of measurements with Sun Simulator, the PV modules $a-S i / \mu c-S i$ after being operated for about 4.5 years the electrical power output had degraded about 29.3\%, and when compared with the specifications according to the label, the decline was about $19.7 \%$. This decline is clearly seen through the parameter known as the curve factor (Fill Factor, FF) with FF $=0.50$, shows the forms of I-V curve of PV module is declivous than $\mathrm{FF}=0.63$ that was obtained from the measurement results at the early assembling of PV module. FF that has value close to 1 is the curve that is near a perfect shape shows the good quality of PV module.

5) The Electric Energy PV Array Results: To date, the electrical energy that is supplied to the grid from PV array at $500 \mathrm{kWp}$ on SMG Sumba is quite large, although during the operation of the SMG Sumba there were several times having problems in components, so that at the certain time SMG system did not operated for improvement. Besides that, the operation in the SMG Sumba has not been handed by the PLN so that there is no employee of the PLN placed in the SMG control center in Bilacenge to optimal the operation. Since the beginning of the operation until February 7, 2014, according to the amount recorded in all of the fifth LCD inverter units, note that PV array has generated electrical energy about $126.833 \mathrm{kWh}$. Meanwhile, from the new measuring tool (kWh meter) recently that installed since July 2014, as shown in Fig. 9, it appears that the electrical energy has been supplied to the grid until April 2016 is about $242.727 \mathrm{kWh}$. Meanwhile, the PV array energy output data from February to June 2014 has not been recorded because there is replacement in the LCD and improvement in the all of fifth inverter units. If we calculated based on these data, the estimation of the amount of electrical energy that has been generated PV subsystem was about $369 \mathrm{MWh}$. If assumed that the value of PV electricity is equivalent to US \$ 25 cents per-kWh, then the PV subsystem has produced the electrical energy equivalent to 1245 billion rupiahs.

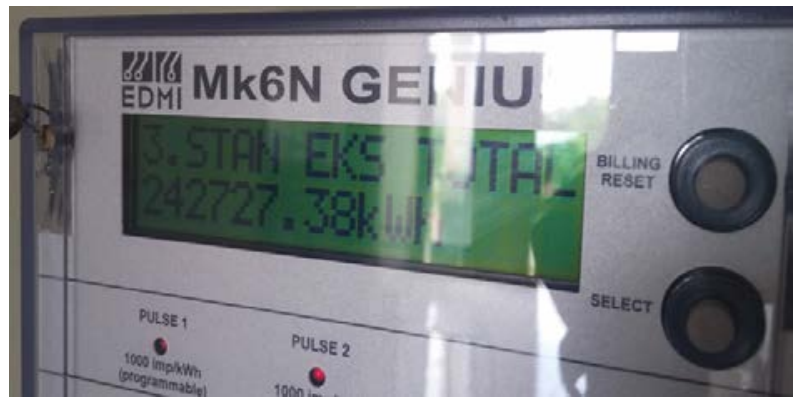

Fig. 9 The kWh meter that installed in SMG Sumba since July 2014.

\section{CONCLUSIONS}

In conclusion, the PV subsystem on Sumba SMG system has contributed significant energy on the electrical system in Southwest Sumba Regency, although the overall of Sumba SMG system has not been able to contribute optimally because there are some problems at the VRB battery subsystem. The implementation of the thin film type PV modules on the SMG Sumba system indicates that there is required knowledge of the thin film type PV cell because of many problems appear in the area, such as an installation problem, decrease of the current-voltage characteristics, and its response that is sensitive to the changes in light intensity. The evaluation results of the SMG Sumba also indicate that the implementation of the VRB batteries is less appropriate in the electrical systems in area with the limited generators, because the VRB requires charging every time so that it will cause the problems at night during peak load.

\section{ACKNOWLEDGMENT}

The researchers would like to express their gratitude to all authorities in PLN of West Sumba Region who have provided facilities and conveniences during our team of B2TKE-BPPT conducted a regular evaluation of the performance in SMG Sumba and the Government of the Southwest Sumba District 
that supported and provided the location and other facilities when the process of construction, operation, and supervision in SMG Sumba were conducted.

\section{REFERENCES}

[1] Zarory, H., Wijaya, F. D. and Sutopo, B.,"Kendali Penyimpan Energi Listrik untuk AplikasiMikrogrid”,JNTETI, Vol. 3, No. 2, 2014.

[2] Sakya, I Made Ro, "Development of Small Island Power System in Indonesia ”, Seminar Nasional Smart grid, November 2014.
[3] Juwito, A. S. \& Haryono, T., “Optimisasi Energi Terbarukan dalam PembangkitanEnergi Listrik Menuju Desa Mandiri Energi di DesaMargajaya”,JNTETI, Vol. 2, No. 3, 2013.

[4] Prastawa, Andhika, dkk., "Pengujian Smart Micro Grid Sumba”, BPPT, 2013.

[5] Akhmad, Kholid, dkk.,"Pengujian dan Pemeliharaan Smart Micro Grid Sumba”, BPPT, 2014. 